\title{
An Exploratory Study on the Changes of Life Perspective after Majoring in Social Welfare: Focus on a Graduate Student
}

\author{
Keoung Yeol Kim ${ }^{1}$ \\ ${ }^{1}$ Associate professor, Department of social welfare, Kwang Shin University (Chosun University \\ Graduate School), South Korea,007powerk3@gmail.com
}

\begin{abstract}
The purpose of this study was to explore the changes in life after majoring in social welfare. To achieve the objective of this study, the researcher drew the results through qualitative case studies, by interviewing the participants. The participants of this study comprised six students in graduate school. This study was carried out in-depth interviews one by one for two months. In-depth interviews were performed targeting a total of six subjects, and their details were used for analysis. To accomplish diversifications of data, this researcher drew the results through qualitative case studies, after interviewing the participants. The major findings of the study were as follows: Firstly, the participants can get a new understanding of social welfare (Understanding the objects of social welfare, Understanding the definition of social welfare, Understanding the meaning of social welfare). Secondly, the participants can experience a change in their lives after majoring in social welfare (Change in church ministry, Change in home life, Change in interpersonal relationships).
\end{abstract}

Keywords: Social Welfare, Social Worker, Education, Qualitative Research

\section{Introduction}

\subsection{Necessity of Research}

The rapid social changes have left all citizens exposed to social risks and social problems. In particular, as the economic situation worsens and unemployment increases, citizens are interested in the benefits and services of social welfare. According to the government's budget plan for the year 2019, the amount of 470.5 trillion won, was increased by 9.7 percent from the previous year. This budget will be used to create jobs, and economic growth, improve income distribution and expand the social safety net. These efforts are based on the philosophy that everyone is a noble being and should be equally respected in any environment, and their rights should be equally guaranteed[1].

Along with the nation's policy efforts, social welfare practical efforts should follow. This includes the preparation of competent social workers for the improvement of the lives of those subjects in the increasing number of social welfare centers. To become a social welfare practitioner, one must be experienced in school education, as well as training from field experts to learn the knowledge, skills, and values that one must have as social welfare professional and apply them into practice[2]. Due to the rapid growth of social welfare departments and the diversification of social welfare- curricula, the number of graduates who majored in social welfare produced annually by schools in social welfare and welfare-related departments across the country has increased[3]. In addition, social workers are produced each year in various ways[4]. After the completion of the education in social welfare, which

Received: July 29, 2020; 1st Review Result: September 16, 2020; 2nd Review Result: October 31, 2020 Accepted: November 30, 2020 
is a practical study, the expectation of the possible changes in the workplace environment post-education life will greatly help to set the direction of future social welfare education. Studies related to the effect or evaluation of social welfare education have mostly been conducted around undergraduates. Furthermore, research on capacity building, career preparation, and elasticity through social welfare field training were dominant among undergraduate major students[5-14]. In this research, we focused on graduate students majoring in social welfare, aiming at finding out the kind of changes that occur in their life as adults after majoring in social welfare. In the face of a lack of research[15-18] on graduate students majoring in social welfare, we would like to find out what changes there are in their lives as adults after majoring in social welfare.

\subsection{Research Problems}

Through the voice of a graduate student majoring in social welfare, this study will be conducted through qualitative methods to get in-depth information on the motivation of social welfare and change in life after majoring in social welfare. The research question of this study is: "What are the changes in life after majoring in social welfare?"

\subsection{Research Methodology}

To achieve the objective of this research, interviews were conducted with students majoring in social welfare in the graduate school master's courses. In other words, samples were obtained through intentional sampling. In this study, it is necessary to have at least three semesters of academic experience in graduate school courses to see the changes in life after majoring in social welfare. Along with this, I conducted a study on six graduate students with more than three semesters of academic experience. The general characteristics of the study participants are shown in [Table 1].

[Table 1] The Characteristics of the Participants by Grades

\begin{tabular}{|c|c|c|c|c|}
\hline & Object of study & Age & Sex & Academic background \\
\hline & Study participant 1 & 45 & Male & $\begin{array}{c}\text { 4th semester } \\
\text { (Master's degree) }\end{array}$ \\
\cline { 2 - 5 } & Study participant 2 & 58 & Male & $\begin{array}{c}\text { 4th semester } \\
\text { (Master's degree) }\end{array}$ \\
\cline { 2 - 5 } $\begin{array}{c}\text { Study } \\
\text { participants }\end{array}$ & Study participant 3 & 46 & Male & $\begin{array}{c}\text { 4th semester } \\
\text { (Master's degree) }\end{array}$ \\
\cline { 2 - 5 } & Study participant 4 & 47 & Female & $\begin{array}{c}\text { 4th semester } \\
\text { (Master's degree) }\end{array}$ \\
\cline { 2 - 5 } & Study participant 5 & 38 & Female & $\begin{array}{c}\text { 4th semester } \\
\text { (Master's degree) }\end{array}$ \\
\cline { 2 - 5 } & Study participant 6 & 39 & Female & $\begin{array}{c}\text { 4th semester } \\
\text { (Master's degree) }\end{array}$ \\
\hline
\end{tabular}

The interview was developed by referring to prior studies related to the topic. When a study participant was unable to express their answer, he or she would be interviewed with the simple questions that lead to the conversation. Additional questions were asked about the experience that was not materialized after the interview. To conceptualize the interview, I explained the meaning of words, sentences, and the context in detail. The concept was derived by coding raw materials, categorizing, and then going through a technical interpretation of the case. For the reliability of the data, efforts were made to carry out a more objective analysis through advice from colleagues in qualitative research. 


\section{Contents}

Graduate students majoring in social welfare, who were participants in the study, understood the main concept after finding the meaning in statements about life changes following majoring in social welfare in graduate school and organized themselves by upper and lower categories. The researcher looked at the similarities and differences between the cases as they continued to compare the individual cases. Nominal results from continuous insights and interpretations can be presented as shown in [Table 2] with six subcategories and two upper categories.

[Table 2] The Change of Life after Studying the Social Welfare Science

\begin{tabular}{|c|c|}
\hline Lower category & Upper category \\
\hline Change of subject's understanding & \multirow{3}{*}{ Changes in understanding the major } \\
\hline Change of understanding of concepts & \\
\hline Change of meaning in one's major & \\
\hline Change of church service & \multirow{3}{*}{ Changes in life } \\
\hline Change of family life & \\
\hline Change of relationship & \\
\hline
\end{tabular}

\subsection{Changes in Understanding the Major}

\subsubsection{Changes in Subject's Understanding}

Participants in the study reported having brought a change of understanding of the object of social welfare upon completion of their study in social welfare. In other words, they understood that the target of social welfare includes not only those who are relatively poor but also all those who seek to change their lives.

As far as it is concerned, I only knew that social welfare is regarded as helping underprivileged people and students along with their studies. It was just a primary idea. However, my findings showed that social welfare is for everyone who works hard for a better life not only for the underprivileged persons.

(Research participants 1)

I thought social welfare was an effort to help people in need, but after majoring in social welfare, I realized that the object of social welfare is not only for those in need but also for all universal human beings. I found the understanding of objects.

(Research participants 2)

Social welfare studies are not simply learning to help people in need, but rather understanding clients, providing them with the right services, the satisfaction of the client, and also creating a healthy society.

(Research participants 3)

Before attending my major, I thought about social welfare easily. However, I thought that social welfare was the foundation of all studies and the top of all studies. I felt while studying graduate school and attended the class. I realized that it is difficult to understand only by knowing various disciplines such as humanities, history, law, psychology, anthropology, etc when I study social welfare. there is humanity, history, psychology, and various studies in social welfare. The reason why I think so is that social workers need to understand the client from the client's sight to provide the right services.

(Research participants 4)

To be honest, that was what I had before my major. "I have to go to help people, help them, and serve them, so I need a license, so I have to get one." So I thought my major was too easy. Many people studied social welfare online or worked at a lifelong education center. My aunt, who is almost 60 years 
old, was working at a social welfare center. So how easily handling would she have treated this study? I understood it as a study for a certificate. approached it with a complacent mind and way of thinking as an amateur, not in preparation as an expert to provide professional services.

(Research participants 5)

Understanding it to the extent of "help someone" I have done in the field of practice in daily life. But after I entered the school and studied, I changed my mind completely. Social welfare is so vast, scientific, and professional that there is no unconnected learning. How many subjects I had to study was a burden. There are so many areas of expertise to study, such as history, politics, economics, law, administration, environment, health care, statistics, social science, etc.

(Research participants 6)

\subsubsection{Change of Understanding Concepts}

While being in social welfare in graduate school, participants' perspective was to get a certificate. Moreover, after completing this major, I acquired knowledge of social welfare through scientific, systematic, and convergent studies.

Interested in Social Welfare. Look at the teenagers, older adults, and needy people in need of living, how can I help them with their difficulties? The thought of it just crossed my mind. Especially when I met runaway youths, I realized that there was nothing I could do for my students, and I just remembered that I couldn't do anything but meet them and listen to them, have a meal at a snack bar with them, and give some money for them.

(Study participant 1)

My understanding of social welfare- concerns "helping someone" before being admitted to that department. But after I joined the school and learned much more, I came up with a better understanding and changed my mind completely. Social welfare is such a vast, scientific, and professional study with no unconnected learning.

(Research participants 2)

I'm just happy as a social worker, for no particular reason, it's just good, fun, exciting, and amazing. loving people and being together, but for me, social welfare is especially comfortable and fun. Isn't it enough if the problem is solved and many people are happy by creating something new? I would like to think if it is my job to solve problems and create new things where people share affection. I think it's for myself. For me, social welfare is my life.

(Research participants 3)

Before majoring in social welfare, thinking about the society and the problems from the counseling perspective which are the person's psychology and surroundings, his family's relationships, and problems from the perspective of "why did he get to do such problems and actions?" and looked at it from the perspective of child-rearing attitudes and various problems that he was forced to be exposed to. Even when I met one person and talked to him, I looked at the person's various situations and psychological aspects. However, as my major was social welfare, this view changed a lot, and my view of society became wider. In other words, I have seen a trend in society and learned about the systemic problems and difficulties of society, unlike the individual focus on any social problem. There is also a view of problems from a welfare perspective.

(Research participants 4)

I was interested in teenagers in the field where I first worked, and later than I was fascinated by the idea of 'what can I do for them?' I started social welfare because I was attracted to them, but I think I need to look around for other areas that I don't know a bit about other centers or social welfare centers outside of the church ministry and find out what I'm going to choose. Although I feel a lot of pressure to experience and practice more in a short time as I started late, so I need to work harder than others 
during my study.

(Study participant 5)

Social welfare studies are not formalized studies, but they should not just be replaced with physical formulas such as " $\mathrm{F}=$ ma." Because the object of service is a person, and the person lives in a rapidly changing time environment. I found it necessary to take a policy, professional, and integrated approach. Finally, not just one social worker, it is that each individual from all the states should work together.

(Research participants 6).

\subsubsection{Changes in the Meaning of Major}

Participants recognized social welfare as a subject just helping others to live happily. Furthermore, I found that social welfare was a job to love people and make small changes in the world and help clients understand it by providing the right service.

It makes me feel grateful to challenge myself and do something that improves someone's life because everyone lives with a problem. I cannot predict what the future reserves for me, thus, excitement and expectation about what the new social welfare work would do elsewhere, and other projects as callings were the reason I chose to study it. I look forward to giving my whole contribution to greet the day all people are happy. I'm proud of myself for doing "social welfare studies," a job that gives people the love to make small changes in the world.

(Research participants 1)

Before attending my major, I thought social welfare is too easy. However, I thought that social welfare was the foundation of all studies and the top of all studies. Studying graduate school and attending the class, I realized that social welfare is difficult to understand. For understanding it precisely, I needed to know there are the humanities, history, psychology, and various studies in social welfare first. The reason I think so is that social workers need to understand the client from the client's sight to provide the right services.

(Research participants 2)

At the time I learned social welfare, I had a strong perception that social welfare concerns just helping others. I thought this domain of social welfare ranked at the lowest level among other fields of study. The reason I had such understanding was the social welfare department in the school did not have any business-administrative components. Since I joined graduate school and learned more, I realized that social welfare was the foundation of all my studies.

(Research participants 3)

It was based on the thoughts I felt while working at social welfare centers and the stories of my friends working as social workers. When people who work in social welfare their job to help people around them make it difficult and hurt, I thought, "What kind of social welfare are they doing when they can't make people around them feel comfortable?" Since then, I think I had have a desire to study social welfare step by step. So I decided to do social welfare, and I was thinking about whether I should go to undergraduate or graduate school for the weekend, but I decided to major in social welfare at graduate school after I was advised whether I needed to go to undergraduate or graduate school again. I could not receive any welfare benefits before my father's death. Although it was difficult for her sister to care alone for a long time and financially, it was difficult to get help, but patients in the same hospital room were receiving welfare benefits even though conditions were much better than ours. I know that these problems need to be improved and that there are improvements. But even I couldn't know where and how to get help when there were such problems and difficulties and couldn't help my sister and father. However, if I study social welfare and work in this field, I also have the vision to teach more people how to get social welfare.

(Study participant 4) 
Understanding it to the extent of "help someone" I have done in the field of practice in daily life. But after I entered the school and studied, I changed my mind completely. Social welfare is so vast, scientific, and professional that there is no unconnected learning. How many subjects I had to study was a burden. There are so many areas of expertise to study, such as history, politics, economy, law, administration, human harm, environment, health care, statistics, social science, etc.

(Research participants 5)

By starting to study social welfare there was no difference in the journey of my life. I saw social welfare as meeting people and creating a better environment, with each other remaining with an enriched beautiful memory of life. I became fond of this study by going in-depth, and through this learning, I want to give practical help and 'beautiful memories of my life to everyone I meet.

(Research participants 6)

\subsection{Changes in Life}

Considering the feedback of graduate students in the social welfare department, this study summarizes the interview details of the question regarding life change that follow the completion of studies in social welfare as follows.

\subsubsection{Changes in Church}

In church, many changes in social welfare were observed. Preaching the gospel and connecting with social welfare services to many people after worship service, played an important role. It is said that the number of conversations with the church members increased and the church members worked together to save the community.

I've met many people before, but I don't think I have ever talked as much as I do now. Homeless people, disabled people, and runaway children were often given a few pennies, and now we can share a lot of things. To look for things that can help in the future, the church should build such social enterprises and create more jobs, and this may be able to help them more practically. And I get it when I talk. Then it looks different. As a pastor, it seems that I have an opportunity to serve people and work harder on soul salvation and social salvation, and a starting point for change.

(Research participants 1)

Since I started to study social welfare, I have visited them every Thursday to consult them. And I asked them if there is anything difficult, and help them. When they needed a car to go to the hospital, I took them there. Elderly people with dementia I visited every week became companions, and when they meet those who are in the upper class of cars in blind spots, they connect them to welfare centers. And while studying social welfare, I shared my thoughts with the church members. I opened the underground space of the church as a table tennis court for the community. Studying the things I hesitated about whether I came to practice boldly. It was a big change.

(Research participants 2)

One Sunday morning while practicing the choir, the deaconess tried to introduce me to social welfare. Of course, I was already terminated job. When I was young, one of the jobs that fit my aptitude was social welfare and art. After all, I wondered if it was my destiny to go this way. I tried to get a job introduction, but it became a problem that I didn't have a license. That's why the deaconess asked me to study social welfare. Deaconess attends graduate school and university in Gwang-ju and gives lectures on social welfare. So the deaconess' husband introduced me to the social welfare department of Kwangshin Graduate School, saying that there is a graduate school where her husband also studied and that it would be better because it is a Christian school.

(Research participants 3)

There were some recipients in our church. I planned a job for their self-supporting. Using the 
remaining space, the company was planning to open a natural fermentation bakery and do business as a social enterprise. The church sponsored the bakery and remodeled the interior and prepared for selling coffee. First, there were many changes in the church. Although many of them were unable to join the ministry due to their working lives, they were drawing a more welfare vision with their husbands, and concentrating their thoughts and minds on the renewal and independence of an individual.

(Research participants 5)

\subsubsection{Changes in Domestic Life}

Unlike before, he studied social welfare and found that he had more time to talk with family members and had trust among family members. It is also said that they have come to share the education and practice of why children should help people in need.

A major change in the family was a trustful relationship with the eldest son (sixth grade in elementary school) who has been absent from home to study. Trust was built up like that, we could naturally understand each other well and believe each other. It was also a big change in making it easier to tell more stories. And we talked about many stories while working in the daytime as a kindergarten teacher and studying with my wife at night. Family life, church life, married life, and vision and study were all very special times. During those times, my wife and I got closer, and it was cool.

(Research participants 2)

Also, I would like to help them have a lot of welfare experiences in their education, even though they were still young. In the meantime, I have helped to know God's gaze and mind in setting a course and talking about an event together. But, I wanted to present a vision to the children of Jesus, who had compassion on God and looked after the orphans and widows, to the needy.

(Research participants 5)

After studying social welfare, I could see that the change in family life was (a little more) magnanimous than I expected. I lived with my brother at home, but he had to do all the housework by himself because he was working and hanging out. And I had to do all the housework by myself, and there were many complaints about my brother and many things to get angry at him before I studied. But after studying social welfare, I started to understand my younger brother. I felt sorry for him who was tired after work. Also, I thought that I should take care of him as a client, so I changed my mind.

(Research participants 6)

\subsubsection{Changes in Interpersonal Relationships}

After majoring in social welfare in graduate school, my perspective of understanding people around me has widened. Also, the eyes of society have changed from individual perspective to overall perspective, which helped to understand people and many other things.

Before majoring in social welfare, I watched society and problems from a counseling perspective. The person's psychology and surroundings, his family's relationships, and problems made me witness the problem from the perspective of why did he get to do such problems and actions? And I viewed it from the perspective of the person's attitude and various problems that he was forced to be exposed to. However, as I majored in social welfare, this view changed a lot and my view of society became wider. In other words, I have seen the overall trend of society and learned about the systemic problems and difficulties of society, unlike the individual focus on social problems.

(Research participants 2)

After studying social welfare, the change in interpersonal relationships has led me to the social worker's mind. When I was walking or driving with my friends, I always saw someone who didn't follow the rules and criticized him, asking why he acted like that. However, after studying social welfare, thinking about what kind of mind that person should act like or what kind of problems he had, and what 
kind of situation he or she would act like, came to mind first rather than criticizing him. When I talked with my friends, I liked to talk rather than listen to them, like my problems were more important than friends, I listened to my friends' stories and gave them sincere advice.

(Research participants 3)

As I majored in social welfare, my attitude toward people has changed. Instead of judging their actions and words first, I attempted to understand why they behave and speak like that.

(Research participants 6)

\section{Conclusions}

This study was conducted to analyze the current status and characteristics of the underprivileged' participation in lifelong education programs. Comparing the cases of individual researchers, two upper categories (changes in major year, life change) and six lower categories (changes in major year, changes in understanding of concepts, changes in meaning of majors, changes in teaching roles, changes in family life and interpersonal relationships) were found. This study found that participants had a new understanding of their major through learning about social welfare. The details of this were a change of understanding of the subject of social welfare', a change of understanding of the concept of social welfare, and a change in the meaning of the major of social welfare studies. First, after majoring in social welfare, participants in the study found that the subjects of social welfare included not only those who were relatively poor but also all those who sought life change. Second, after majoring in social welfare, research participants came to understand the concept of social welfare as scientific, systematic, and convergent academic rather than learning to have a certificate. Third, after majoring in social welfare, participants came to understand that the meaning of social welfare is not simply to help others but to love people to make small changes in the world and to help them understand from the perspective of clients to provide the right services. This study shows that participants who did not major in social welfare during their undergraduate years have a great experience in changing their major interests. In other words, education on actual social welfare shows that understanding of social welfare majors has been expanded.

Based on these characteristics, the following proposals were made as a way to activate lifelong education for the underprivileged. The details of this are influencing church service, affecting family life, and change in personal relationships. First, participants in the study experienced a change in the role of the church after majoring in social welfare. In other words, they have come to preach the gospel to many people who come on weekdays and to try to solve the problems of their lives. Second, research participants experienced changes in family life after majoring in social welfare. While studying social welfare, they came to respect and trust their family members. It was also a great help in terms of education for children. Third, participants in the study experienced a change in interpersonal relationships after majoring in social welfare. In conclusion, when dealing with people after majoring in social welfare, they started to think in context from a holistic perspective, not from an individual perspective.

\section{Acknowledgments}

This is similar to the study result[19-20] that social welfare majors have had self-reflection and reflective thinking since their experience in the "Quality Research Methodology" class. There is also a study in the pedagogical circles[21-22] that has brought about reflective thinking through education as a related study.

This study has the limitation that there are fewer cases to achieve the purpose of the study. Through this study, we could confirm that changes in major knowledge and reflections on life occur through 
social welfare education. We hope to continue to study the experiences of students majoring in social welfare in undergraduate and graduate courses.

\section{References}

[1] K. Y. Kim, Case Study on the Experiences of Job for Employed People with Mental Disabilities, The Journal of Humanities and Social science, (2018), Vol.9, No.2, pp.895-906, DOI: 10.22143/HSS21.9.2.71

[2] Y. N. Goo, H. J. Sung, A Study on the Supervision of Adolescence Internship program - The Agency of Mental Health in Daegu City, Journal of Welfare Administration, (2004), Vol.14, No.1, pp.93-117.

[3] S. W. Jong, E. Y. Han, A Study of Social Work Students' Volunteering and Competence of Social Work Practice: Analysis on Moderator Effect of Social Worker's Supervision, Korean Journal of Social Welfare Education, (2013), Vol.23, pp.93-120, UCI: G704-SER000010583.2013.23..002

[4] D. H. Kim, Impact of prospective social worker's capability and empowerment on social policy well-being -With Prospective Social Workers living in "K" and "D" City-, Asia-pacific Journal of Multimedia Services Convergent with Art, Humanities, and Sociology, (2017), Vol.7, No.4, pp.425-432.

[5] S. Y. Choi, Effects of Intrinsic-Extrinsic Work Value and Job Seeking Stress on Career Attitude Maturity of Social Work Students, Asia-pacific Journal of Multimedia Services Convergent with Art, Humanities, and Sociology, (2017), Vol.7, No.10, pp.787-796, DOI: 10.35873/ajmahs.2017.7.10.072

[6] S. Y. Choi, A Study on the Antecedents of Social Work Students' Career Decision Efficacy: Focusing on the Effects of Career Barriers and Satisfaction from Major, Asia-pacific Journal of Multimedia Services Convergent with Art, Humanities, and Sociology, (2016), Vol.6, No.10, pp.345-353, DOI: 10.35873/ajmahs.2016.6.10.033

[7] S. J. Kim, The Study of Vocational Value Subtypes of College Students, The Journal of Career Education Research, (2013), Vol.26, No.1, pp.93-117, UCI: G704-001285.2013.26.1.010

[8] S. M. Jang, S. Y. Kyoung, The Job-seeking Stress, and Addictive Behaviors among College Students: Focused on the Mediating Effect of Anxiety, Health, and Social Welfare Review, (2013), Vol.33, No.4, pp.518-546, DOI: 10.15709/hswr.2013.33.4.518

[9] M. S. Yoon, H. S. Lee, The Relationship between Depression, Job Preparing Stress and Suicidal Ideation Among College Students: Moderating Effect of Problem Drinking, Korean Journal of Youth Studies, (2012), Vol.19, No.3, pp.109-137, UCI: G704-000387.2012.19.3.012

[10] K. H. Ha, B. C. Kang, The Study on Factors Affecting Social Work Majoring Undergraduates' Attitude to Human Rights, Korean Journal of Social Welfare Studies, (2009), Vol.40, No.2, pp.183-202, DOI: 10.16999/kasws.2009.40.2.183

[11] J. N. Yang, E. J. Choi, Y. R. Moon, G. Y. Park, S. H. Park, A study on how social work student's self-efficacy and advocacy effects multicultural receptiveness, Korean Journal of Social Welfare Education, (2011), Vol.16, No.16, pp.24-47, UCI: G704-SER000010583.2011.16.16.001

[12] D. S. Son, Y. G. Moon, A Study on the influence factors the resilience of social welfare majors in college, Korean Journal of Social Welfare Education, (2011), Vol.16, No.16, pp.48-69, UCI: G704-SER000010583.2011.16.16.003

[13] H. J. Lee, The Perception of Hospice Social Worker's Role and Hospice Care among College Students Majoring Social Welfare, Korean Journal of Social Welfare Education, (2013), Vol.24, pp.81-99, UCI: G704SER000010583.2013.24..005

[14] W. J. Lee, A Study on the Effect of the Social Welfare Students' Perception for Exam Cheating on their Perception for a Whistle-Blowers in Social Welfare Organizations -focused on the Mediation Effect of Social Responsibility and the Moderation Effect of the Will for Blowing the Whistle on the Cheating-, Journal of School Social Work, (2017), No.38, pp.201-224.

[15] H. S. Chong, M. J. Choi, J. J. Yu, A Study on Social Welfare Graduate Students' Experiences With a Class of Qualitative Research Method, Korea Journal of Social Welfare Education, (2010), Vol.12, pp.97-121, UCI: G704- 
SER000010583.2010.12..007

[16] Y. S. Gang, MSW Students' Perceptions of Effective Social Work Field Supervision, Center For Social Welfare Research Yonsei University, (2011), Vol.28, pp.169-198, UCI: G704-002139.2011.28..002

[17] S. M. Cho, J. S. Chun, Factors associated with supervision satisfaction in graduate social work field practicum, Korean Journal of Social Welfare Education, (2009), Vol.10, No.10, pp.119-141, UCI: G704-SER000010583.2009.10.10.007

[18] Y. M. Moon, S. Y. Park, H. R. Kang, A Study on the Discrimination and Coping Experience of Graduate Students with Disabilities - Surviving from Microaggressions in Performance-Based Graduate School, Korean Journal of Qualitative Research in Social Welfare, (2019), Vol.13, No.3, pp.123-150, DOI: 10.22867/kaqsw.2019.13.3.123

[19] H. S. Chong, M. J. Choi, J. J. Yu, A Study on Social Welfare Graduate Students' Experiences With a Class of Qualitative Research Method, Korean Journal of Social Welfare Education, (2010), Vol.12, pp.97-121, UCI: G704SER000010583.2010.12..007

[20] Y. S. Gang, MSW Students' Perceptions of Effective Social Work Field Supervision, Center For Social Welfare Research Yonsei University, (2011), Vol.28, pp.169-198, UCI: G704-002139.2011.28..002

[21] X. Y. Ding, K. E. Kim, B. K. Cho, Pre-service early childhood teacher's experience of reflection on early childhood science class, Asia-pacific Journal of Multimedia Services Convergent with Art, Humanities, and Sociology, (2018), Vol.8, No.6, pp.349-358, DOI: 10.35873/ajmahs.2018.8.6.031

[22] J. A. Lee, Development of a class model to enhance the adaptation of university life for Underachieving students, Asia-pacific Journal of Multimedia Services Convergent with Art, Humanities, and Sociology, (2018), Vol.8, No.12, pp.375-384, DOI: 10.35873/ajmahs.2018.8.12.036 